\title{
Law Enforcement against Traffic Accident
}

\author{
Rio Tumiyadi Maulana ${ }^{*}$, and Sri Kusriyah ${ }^{* *}$ ) \\ ${ }^{*}$ Student of Master of Law, Faculty of Law, Universitas Islam Sultan Agung Semarang, \\ E-mail: riotm33@gmail.com \\ ${ }^{* *}$ Lecturer of Master of Law, Faculty of Law, Universitas Islam Sultan Agung Semarang
}

\begin{abstract}
The purpose of this study is as follows: To determine and analyze the factors that cause traffic accidents. To find out and analyze law enforcement against traffic accidents. To find out and analyze barriers in traffic accident law enforcement and their solutions. The approach used by the author to discuss the above problems is to use a sociological juridical approach, namely approaching the problem through legal research by looking at the legal norms that apply in society. The research specification used in this research is descriptive analytical. Based on the results of this study, the factors that cause traffic accidents include: the driver / driver is sleepy, the factor of the vehicle itself, road factors, environmental factors. Law enforcement against traffic accidents can be carried out by applying the provisions of Act No. 22 of 2009 concerning road traffic and transportation Article 310 if it concerns handling traffic accidents for negligence of drivers, either resulting in death or only injury. Obstacles in law enforcement of traffic accidents is the participation of the community, police officers, local governments at level I and level II as well as the role of the central government to work together to create a safe, comfortable and peaceful environment for the community. Efforts to overcome obstacles in traffic accident law enforcement are as follows: (a). Making efforts on the Government's side to revise the Articles in Act No. 22 of 2009 concerning road traffic and transportation; (b). Increase the number of personnel for the realization of maximum service; (c). Doing morning apples on roads that are at the heart of traffic problems; and D). Fostering legal awareness of the community to obey the law in traffic.

Keywords: Law Enforcement; Accidents; Traffic.
\end{abstract}

\section{Introduction}

In the life of the nation and state, security is a determining factor in the life of the nation and the state of implementing a sovereign and authoritative government, which is the main condition that supports the realization of a just, prosperous, prosperous and civilized life in a civil society system based on Pancasila and the Constitution of the Republic of Indonesia. 1945 Indonesia. Domestically, the National Police carries out law enforcement efforts through the process of investigating and investigating criminal acts as regulated in Act No. 2 of 2002 concerning the Indonesian National Police. ${ }^{1}$

Road Traffic and Transportation has a strategic role in supporting national development and integration as part of efforts to advance public welfare. The development of the Traffic and Road Transportation sector is carried out jointly by all related agencies. Road traffic and transportation is a unitary system consisting of

\footnotetext{
${ }^{1}$ Ni Made Srinitri, Umar Ma'ruf, Progressivity Of Criminal Handling Fraud And Disease By The Directorate Of The General Criminal Reserse Of Central Java Regional Police (POLDA), Jurnal Daulat Hukum Volume 3 Issue 1, March 2020 ISSN: 2614-560X
} 
Traffic, Road Transportation, Road Traffic and Transportation Network, Road Traffic and Transportation Infrastructure, Vehicles, Drivers, Road Users and their management. $^{2}$

As a country based on law in achieving the goals of national and state life, especially the achievement of community welfare in development as a mandate of the Preamble to the 1945 Constitution of the Republic of Indonesia, the road traffic and transportation system has a strategic role as a means of smoothing the flow of goods and services transportation. ${ }^{3}$ Traffic and Road Transportation (LLAJ) has to develop its potential and role to realize security, welfare, traffic order and road transportation in the framework of supporting economic development and development of science and technology, regional autonomy, and accountability of state administration.

Almost every day people in carrying out their daily activities use the road. A highway, which is a road in any form that is open to public traffic, is already one of the basic necessities of the community. Naturally, the community members using the highway are subject to regulations regarding road traffic and transportation. In order for the highway which is the basic necessity of the community to really function, certain regulations regarding order and security and safety are required.

One of the problems that are always faced in big cities is the problem of traffic. This is evident from the indication that the number of traffic accidents is always increasing. This situation is a manifestation of the development of modern technology. The development of traffic itself can have an impact, both negative and positive in the life of the community. As is known, the number of vehicles in circulation from year to year is increasing. This clearly has an impact on traffic safety in the form of traffic violations that cause traffic accidents and traffic jams.

The people's mindset in driving on the highway has given birth to an instant society both when driving and outside driving. This instant society then encourages the flexibility of ethics in driving on the highway, and causes various kinds of traffic violations. Violation is a criminal act that is not as serious as a crime. Meanwhile, according to the large Indonesian dictionary, a violation is an act or case of violation, a crime that is lighter than a crime. ${ }^{4}$

The importance of transportation is reflected in the increasing need for transportation services for the mobility of people and goods from and to all corners of the country, even from and abroad. In addition, transportation also plays a role as a support, impetus and driver for potential regional growth, however underdeveloped, in an effort to increase and equalize development and its results. ${ }^{5}$

The ability to drive vehicles, both motorized and non-motorized vehicles on the road, will have a major effect on the traffic situation, vehicle control skills are an absolute necessity for security, safety, order and smoothness of traffic for both the driver / driver of the vehicle and road users. other.

\footnotetext{
${ }^{2}$ General provisions of Act No 22 Year 2009 concerning Road Traffic and Transportation

3 Pietersz. (2010). Karakteristik Surat Tilang dalam Penindakan Pelanggaran Lalu Lintas dan Angkutan Jalan. Jurnal Sasi Vol. 16 No. 3 Bulan Juli - September 2010.

${ }^{4}$ Sudarsono. (2005). Kasus Hukum. Jakarta: Rineka Cipta. p. 106

${ }^{5}$ Kansil, C.S.T. dkk. (1995). Disiplin Berlalu Lintas di Jalan Raya. Jakarta: Rineka Cipta. p. 4
} 
The existence of Act No. 22 of 2009 concerning Road Traffic and Transportation can be used as input for various parties involved, including the Police in particular and the public in general as users of traffic facilities and infrastructure. The police are a government institution whose job is to disseminate information to the public. Meanwhile, the government has a goal of realizing road traffic and transportation that is safe, secure, fast, smooth, orderly and orderly, comfortable and efficient. ${ }^{6}$

The objectives of this study are as follows: To determine and analyze the factors that cause traffic accidents, to determine and analyze law enforcement against traffic accidents, and to determine and analyze barriers to law enforcement of traffic accidents and their solutions.

\section{Research methods}

The approach used by the author to discuss the above problems is to use a sociological juridical approach, namely the approach to the problem through legal research by looking at the legal norms that apply in society.. ${ }^{7}$ The research specification used in this research is descriptive analytical.The data collection method in this research is secondary data obtained from literature study. The data analysis method used is qualitative juridical methods, namely data analysis techniques on methods of analysis

\section{Result and Discussion}

\subsection{Factors That Cause Traffic Accidents}

The fatality rate of a traffic accident is measured by the result of the accident. the more victims who die as a result of the accident, the higher the fatality of the traffic accident. This fatality rate is measured by certain coefficients. Likewise in taking steps to reduce the number of accidents, the fatality rate of an accident must be reduced, of course by paying attention to and prioritizing the safety factor in driving by complying with applicable regulations. ${ }^{8}$

There are several new developments that have not been accommodated by regulatory traffic. For example, a variety of alarms that should be more. Although some regulations have been accommodated through Regional Regulations (Perda). Many provisions are left behind due to the development of society, apart from many laws and customary regulations, which become unenforceable. For example, the need to maintain nighttime lighting for motorized or motorized vehicles hardly applies to goods and bicycle rickshaws. Repression against them is almost never carried out, or if it does, creates an uncomfortable reaction for the officers themselves. ${ }^{9}$

Factors that cause traffic accidents include: drowsiness of the driver / driver, factors of

\footnotetext{
${ }^{6}$ Soekanto, Soerjono. (1995). Kejahatan dan Penegakan Hukum di Indonesia. Jakarta: Rineka Cipta. p. 6

${ }^{7}$ Soekanto, Soerjono. (2010). Pengantar Penelitian Hukum. Jakarta: UI-Press. p. 12

${ }^{8}$ Dadik Purnomo, Jawade Hafid, Peran Sat Lantas Polres Rembang Dalam Menekan Angka Kecelakaan Lalu Lintas, Jurnal Daulat Hukum Vol. 1. No. 1 March 2018 ISSN: 2614-560X.

${ }^{9}$ Anton Susanto1, Ira Alia Maerani and Maryanto, Legal Enforcement by the Police against Child of Criminal Doer of a Traffic Accident Who Caused Death (Case Study in Traffic Accident of Police Traffic Unit of Cirebon City Police Juridiction), Jurnal Daulat Hukum Volume 3 Issue 1, March 2020 ISSN: 2614560X.
} 
the vehicle itself, road factors, environmental factors.

According to the author Factors-Factors that cause traffic accidentsanalyzed by law enforcement theory that the implementation of laws and implementation of judges decisions. The real problem of law enforcement lies in the factors that influence it.

\subsection{Law Enforcement Against Traffic Accidents}

Traffic crime is one of the various forms of criminal acts that occur in society. Whether we realize it or not, road traffic crime is something that often occurs, but sometimes it is not considered a criminal act, but something that usually occurs in traffic.

Law enforcement in modern society is not only defined in a narrow sense but also in a broad sense, such as in Indonesia, law enforcement is associated with the human element and the social environment. ${ }^{10}$ Law enforcement efforts are in line with the principles of the Republic of Indonesia, namely Pancasila. Law enforcement is a prerequisite for a rule of law, law enforcement always involves humans in it and thus will involve human behavior as well. In essence, criminal law enforcement efforts are also part of law enforcement efforts and are often said to be political or criminal law policies which are part of law enforcement policies. ${ }^{11}$

Traffic in Indonesia is regulated in statutory regulations, namely Act No. 22 of 2009 concerning Road Traffic and Transportation, where these regulations are made to ensure security, order and welfare in society which need to be determined regarding prohibited and required actions. Meanwhile, violations of these provisions are punishable by punishment. The frequent occurrence of traffic violations, both intentional and unintentional, may be due to the light sanctions imposed on the perpetrators of traffic violations, so it is not surprising that more and more traffic violations occur. ${ }^{12}$

Basically, the Law Enforcement activity program is not oriented towards finding fault from road users but is more oriented towards the protection, protection and services of road users who violate itself (Enforcement of violations of helmets, seat belts and motor vehicle accessories), other road users (enforcement of SIM violations, speed, signs, markers and others) as well as the interest of disclosing criminal cases (enforcement of STNK violations, frame numbers, machine numbers and others). ${ }^{13}$ Law enforcement against traffic accidents This can be done by applying the provisions of Act No. 22 of 2009 concerning road traffic and transportation, Article 310 if it concerns handling traffic accidents for the negligence of the driver, either resulting in death or only injury.

According to the author, law enforcement against traffic accidents is analyzed from the point of view by using law enforcement theory that the authority to do or not to act, an obligation is a burden or a task of a certain role, can be translated into elements.

\footnotetext{
${ }^{10}$ Poernomo, Bambang. (2001). Kapita Selekta Sistem Peradilan Pidana. Universitas Jayabaya. p. 3.

${ }^{11}$ Arief, Barda Nawawi. (1996). Bunga Rampai Kebijakan Hukum Pidana. Jakarta: PT. Citra Aditya Abadi. p. 29

12 Muhammad Dani Hamzah, Penegakan Hukum Pada Kasus Tindak Pidana Kecelakaan Lalu Lintas Yang Menyebabkan Hilangnya Nyawa Orang, Jurnal Daulat Hukum, Vol. 1. No. 1 March 2018 ISSN: 2614-560X

13 Muhammad, Farouk. (1999). Praktik Penegak Hukum (Bidang Lalu Lintas). Jakarta: Balai Pustaka. p. 33.
} 


\subsection{Barriers to Law Enforcement of Traffic Accidents and their solutions}

Traffic accidents that have occurred so far are caused by negligence, negligence, carelessness experienced by the driver. In general, traffic accidents involving private vehicles and public vehicles are caused by several factors, including drivers, pedestrians, and unsupported infrastructure. The main driver error is a lack of caution when driving a vehicle. ${ }^{14}$

Traffic accidents often occur in people's lives, even the perpetrators are often underage. This is due to a lack of legal awareness and supervision from parents so that children are allowed to drive motorized vehicles before having a SIM. ${ }^{15}$

Barriers to traffic accident law enforcement there is the participation of the community, police officers, local governments at level I and level II as well as the role of the central government to work together to create a safe, comfortable and serene environment for the community.

Efforts to overcome obstacles in traffic accident law enforcement are as follows: (a). Making efforts on the Government's side to revise the Articles in Act No. 22 of 2009 concerning road traffic and transportation; (b). Increase the number of personnel for the realization of maximum service; (c). Doing morning apples on roads that are at the heart of traffic problems; and D). Fostering legal awareness of the community to obey the law in traffic.

According to the author, the obstacles in law enforcement of traffic accidents and their solutions are analyzed from the point of view by using the theory of criminal responsibility according to the Islamic perspective that the act against the law itself is multilevel, so the responsibility is graded according to the level of the act against the law. This level is caused by a person's crime which is closely related to his Qasad (intention).

\section{Closing}

Factors that cause traffic accidents include: drowsiness of the driver / driver, factors of the vehicle itself, road factors, environmental factors. Law enforcement against traffic accidents can be carried out by applying the provisions of Act No. 22 of 2009 concerning road traffic and transportation Article 310 if it concerns handling traffic accidents for negligence of drivers, either resulting in death or only injury.

Barriers to traffic accident law enforcement there is the participation of the community, police officers, local governments at level I and level II as well as the role of the central government to work together to create a safe, comfortable and serene environment for the community. Efforts to overcome obstacles in traffic accident law enforcement are as follows: (a). Making efforts on the Government's side to revise the Articles in Act No. 22 of 2009 concerning road traffic and transportation; (b). Increase

\footnotetext{
${ }^{14}$ Syakiar, Unit Pratimaratri, Deaf Wahyuni Ramadhani, Pelaksanaan Penyidikan Terhadap Anak Pelaku Pelanggaran Lalu Lintas Yang Mengakibatkan Korban Meninggal Dunia (Studi: Polresta Padang), Jurnal Penelitian, (http://www.ejurnal.bunghatta.ac.id, accessed November).

${ }^{15}$ Preliyanto Puji Utomo, Umar Ma'ruf, and Bambang Tri Bawono, Application Of Act No. 22 Of 2009 As A Traffic Accidents Countermeasures Management In The Blora Police Law Area, Jurnal Daulat Hukum Volume 3 Issue 2, June 2020 ISSN: 2614-560X
} 
the number of personnel for the realization of maximum service; (c). Doing morning apples on roads that are at the heart of traffic problems; and D). Fostering legal awareness of the community to obey the law in traffic.

It is advisable for law enforcers to conduct socialization more frequently and be more assertive in conducting supervision. It is advisable for law enforcers to use more speed guns. With the facilities that support law enforcement against cases of violation of the speed limit, it can run smoothly and to be even more assertive in realizing the objectives of the law itself.

\section{References}

\section{Journals:}

[1] Anton Susanto1, Ira Alia Maerani and Maryanto, Legal Enforcement by the Police against Child of Criminal Doer of a Traffic Accident Who Caused Death (Case Study in Traffic Accident of Police Traffic Unit of Cirebon City Police Juridiction), Jurnal Daulat Hukum Volume 3 Issue 1, March 2020 ISSN: 2614-560X.

[2] Dadik Purnomo, Jawade Hafid, Peran Sat Lantas Polres Rembang Dalam Menekan Angka Kecelakaan Lalu Lintas, Jurnal Daulat Hukum Vol. 1. No. 1 March 2018 ISSN: 2614-560X.

[3] Muhammad Dani Hamzah, Penegakan Hukum Pada Kasus Tindak Pidana Kecelakaan Lalu Lintas Yang Menyebabkan Hilangnya Nyawa Orang, Jurnal Daulat Hukum, Vol. 1. No. 1 March 2018 ISSN: 2614-560X

[4] Ni Made Srinitri, Umar Ma'ruf, Progressivity Of Criminal Handling Fraud And Disease By The Directorate Of The General Criminal Reserse Of Central Java Regional Police (POLDA), Jurnal Daulat Hukum Volume 3 Issue 1, March 2020 ISSN: 2614-560X

[5] Pietersz. (2010). Karakteristik Surat Tilang dalam Penindakan Pelanggaran Lalu Lintas dan Angkutan Jalan. Jurnal Sasi Vol. 16 No. 3 Bulan Juli - September 2010.

[6] Preliyanto Puji Utomo, Umar Ma'ruf, and Bambang Tri Bawono, Application Of Act No. 22 Of 2009 As A Traffic Accidents Countermeasures Management In The Blora Police Law Area, Jurnal Daulat Hukum Volume 3 Issue 2, June 2020 ISSN: 2614-560X

[7] Syakiar, Unit Pratimaratri, Deaf Wahyuni Ramadhani, Pelaksanaan Penyidikan Terhadap Anak Pelaku Pelanggaran Lalu Lintas Yang Mengakibatkan Korban Meninggal Dunia (Studi: Polresta Padang), Jurnal Penelitian, (http://www.ejurnal.bunghatta.ac.id, accessed November).

\section{Books:}

[1] Arief, Barda Nawawi. (1996). Bunga Rampai Kebijakan Hukum Pidana. Jakarta: PT. Citra Aditya Abadi.

[2] Kansil, C.S.T. dkk. (1995). Disiplin Berlalu Lintas di Jalan Raya. Jakarta: Rineka Cipta.

[3] Muhammad, Farouk. (1999). Praktik Penegak Hukum (Bidang Lalu Lintas). Jakarta: Balai Pustaka.

[4] Poernomo, Bambang. (2001). Kapita Selekta Sistem Peradilan Pidana. Universitas Jayabaya. 
[5] Soekanto, Soerjono. (1995). Kejahatan dan Penegakan Hukum di Indonesia. Jakarta: Rineka Cipta.

[6] Soekanto, Soerjono. (2010). Pengantar Penelitian Hukum. Jakarta: UI-Press.

[7] Sudarsono. (2005). Kasus Hukum. Jakarta: Rineka Cipta. 